\title{
Determinants of Liquidation of Government Securities Held by Banks in Uganda
}

\author{
Kenneth Alpha Egesa ${ }^{1}$, Bruno Max Ocaya ${ }^{2}$, Leonard Kiboijana Atuhaire ${ }^{2}$, Yeko Mwanga ${ }^{2}$, \\ Tom Nyanzi Makumbi ${ }^{2}$, Xavier Mugisha ${ }^{2}$ \\ ${ }^{1}$ Department of Statistics, Bank of Uganda, Kampala, Uganda \\ ${ }^{2}$ Department of Statistics and Actuarial Sciences, College of Business and Management Sciences, Makerere University, Kampala, Uganda
}

Email address:

kenneth.egesa@gmail.com (K. A. Egesa), bocaya@isae.mak.ac.ug (B. M. Ocaya), latuhaire@isae.mak.ac.ug (L. K. Atuhaire), ymwanga@isae.mak.ac.ug (Y. Mwanga), tmnyanzi@isae.mak.ac.ug (T. N. Makumbi), mugisha.xavier@gmail.com (X. Mugisha)

\section{To cite this article:}

Kenneth Alpha Egesa, Bruno Max Ocaya, Leonard Kiboijana Atuhaire, Yeko Mwanga, Tom Nyanzi Makumbi, Xavier Mugisha. Determinants of Liquidation of Government Securities Held by Banks in Uganda. International Journal of Economics, Finance and Management Sciences. Vol. 3, No. 3, 2015, pp. 285-293. doi: 10.11648/j.ijefm.20150303.25

\begin{abstract}
This study analyzed the determinants of bank liquidation of government securities using panel logistic regression. The analysis showed that the liquidation of government securities by banks was motivated by reserve needs although some evidence of reluctance to borrow from the Central Bank was also noted. The main policy implications of the study include the need to minimize liquidity shortages in the interbank market and development of the secondary market as measures that can minimize liquidation of securities.
\end{abstract}

Keywords: Commercial Banks, Liquidation of Government Securities, Panel Logistic Regression

\section{Introduction}

Commercial banks in Uganda can access liquidity from the Central Bank through three main channels. One way is through sales of foreign exchange to the Central Bank if they have more foreign exchange relative to their requirements or have a liquidity need that can be offset through sales of foreign exchange. The other two ways are related and entail either the sale of Government securities to the Central Bank at a rediscount rate (also referred to as rediscounting) or accessing collateralized loans. In this paper, the focus of the analysis is on the liquidation of Government securities through rediscounts and access to collateralized loans at the bank rate. This type of borrowing from the Central Bank world over has been referred to by several names including member bank borrowing, adjustment credit, discount window borrowing, reserve borrowing and accessing free reserves. When banks liquidate their securities, some distortions may occur which affect either monetary policy objectives or fiscal policy objectives. For instance if monetary policy objective is to tighten liquidity then liquidation of securities by banks acts contrary to policy objectives by adding liquidity. For fiscal, if securities are intended for financing the budget, then liquidation of securities held by banks implies that the
Government has to retire the borrowing prematurely if it is to avoid a borrowing from the Central Bank or larger subsequent issues. It is therefore important to understand the factors that influence commercial banks liquidation of securities in order to identify some potential measures that can mitigate such occurrences due to their disruptive potential.

Theoretically liquidation of securities by banks is determined by the opportunity cost of holding reserves, the need for reserves, and accommodation of the demand for loans In addition banks face costs when rebalancing their portfolios which may result in reluctance to liquidate securities. This study therefore distinguished three potential hypotheses open to investigation as follows:

- An increase in the rediscount lending spread results in an increase in liquidation of Government securities.

- A decrease in bank reserve requirements leads to a decrease in liquidation of Government securities.

- An increase in the demand for loans leads to an increase in the liquidation of Government securities.

The rest of the paper provides a review of the literature on the determinants of liquidation of securities in section 2, describes the data and methodology used for the study in section 3, presents the results and discussion of the results in sections 4 and 5 and ends with a conclusion in section 6 . 


\section{Literature Review}

In general, the liquidation of Government securities held by banks can be linked to the literature on the demand for free reserves, borrowed reserves and rediscounting. Free reserves comprise assets held by banks which can be readily transformed into money. These include excess reserves (banks' holdings of Central Bank money in excess of the required reserves) and domestic money market securities. Government securities comprise the entirety of domestic money market securities in the case of Uganda. On the other hand borrowed reserves refer to reserves held by banks mobilized by borrowing using the Central Bank's discount window. Borrowing from the discount window entails providing Government securities as collateral which implicitly is equivalent to surrendering Government securities held in preference for cash.

The demand for liquidating Government securities is abound with two distinct and opposing views on why banks may liquidate Government securities. These can be broadly referred to as the profit theory and the residual theory ([1], [2], [3] and [4]). In the residual theory, there are three alternative hypotheses comprised of the reluctance, need and accommodation hypothesis.

\subsection{Profit Theory}

Under the profit theory, banks are profit maximizing agents that liquidate Government securities whenever opportunities to invest in assets that earn higher yields become available. [1] noted that starting out from a position of equilibrium, if the discount rate falls relative to the treasury bill rate, banks respond by increasing their borrowings from the Federal Reserve Bank. The reason is that they find such additional borrowings more attractive than the sale of treasury bills as a means of adjusting their reserve positions. Thus, the greater the spread, the larger the volume of borrowings. Conversely, if the discount rate rises relative to the treasury bill rate, this would result in a smaller aggregate volume of bank indebtedness, since the relative cost of such borrowings would have increased. This implies that commercial banks responses to market developments determine their portfolio allocation choices. Rediscounting would therefore be interest rate elastic and relative interest rates would be the key determinant. Some of the earliest empirical results confirming the profit theory were provided by [5] who showed statistically significant effects of the spread for banks in the USA. [6] also found a statistically significant interest rate spread effect on the volume of rediscounting. The short-run semi elasticity with respect to the interest rate spread was found to be 0.84 and showing the predicted sign.

Extensions were made to cater for the cost of foreign substitutes to rediscounting at the Central Bank by [3]. The inclusion of the foreign interest rate and exchange rate premium was motivated by the recognition of international activities of banks and how such activities affect the monetary base's foreign component. The rationale applied was that foreign borrowing sources provided alternative funds to fund the balance sheet constraint relative to liquidation of securities. In the study it was assumed that bank's borrowings from the rest of the world in foreign currency where the domestic public is allowed to maintain foreign currency deposits could be translated into foreign currency loans extended to the domestic public. Such banks faced a foreign interest rate cost and insured against exchange rate risk through the forward market. However, [4] made a valid argument against including the effect of foreign borrowing on the grounds of interest rate parity conditions prevailing in money and capital markets.

[7] employed a non-linear model after deriving a demand function for borrowed reserves which conformed to a switching behaviour. The switching behaviour in the model was found to be dependent on the size of the interest rate spread relative to some switching point confirming the profit theory. The switching point was identified by way of a search procedure based on a maximum likelihood criterion. The results were also compared with a non-switching model which also showed a significant effect of the interest rate spread. The comparison however showed that the switching regression model was superior theoretically and empirically given the influence of the spread to the non-switching linear model in explaining the demand for borrowed reserves from the Federal Reserve.

[8] also found a significant effect of the spread on bank borrowing for banks in USA. However, the results indicated a low sensitivity of borrowing to the interest rate spread. In recognition of the low sensitivity of borrowing to the spread, [8] split the interest rate spread into two components. One component was the spread between the targeted federal funds rate and the discount rate (intended spread) and the second was the spread between the actual federal funds rate and the targeted federal funds rate (unintended spread). The study found a statistically significant but small effect of the intended spread on borrowing and a much larger (four time larger) and significant effect of the unintended spread on borrowing. A test of equality of the two spreads was rejected and the conclusion from the study was that the standard measure of the borrowing function combined two effects. One effect was a response to temporary changes in interest rates and the other was a response to permanent changes in the spread. The strong sensitivity to the unintended spread was attributed to banks willingness to substitute borrowing inter-temporally. A temporary increase in the Federal funds rate triggered a larger increase in borrowing relative to a persistent increase due to the fact that benefits from the borrowing would be higher on the date of the temporary increase relative to other days. However, in Uganda's case splitting the spread in this manner may not yield much analytical usefulness because the difference between the actual and targeted CBR has been zero for the most part of the period and even where there is a deviation it tends to be mean reverting to zero due to regular Central Bank actions to restore stability.

Additional evidence of the profit theory was provided by [9]. The results of the study showed that under a Federal funds rate target, when the spread was relatively predictable and shocks were less persistent, borrowing was very sensitive to 
changes in the spread when the spread was positive. Under a non-borrowed reserves target, when the spread was much more variable and shocks to the spread were more persistent, bank borrowing became less sensitive to the spread. Further, the study showed that after the switch to contemporaneous reserve accounting under unborrowed reserves targeting, shocks to the spread became more persistent and bank borrowing became even less sensitive to the spread.

The literature on the analysis of the effect of the spread on borrowing however also shows that for USA banks, the effect broke down post 1987 ([10], [11], [12], [13], and [14]). This period coincided with the 1987 stock market crush. Both [10] and [11] attributed the breakdown in the relationship to Federal Reserve Bank non-price rationing at the discount window. [13] attributed the decline in the relationship to improved reserve management efficiency and fears that discount window borrowing would be misconstrued by the public as financial weakness. [14] confirmed with their results, the break in the relationship and like [15] agreed that where cost was a function of the frequency, then a negative relationship could exist between borrowing and the spread.

[16] also found a break in the sensitivity of the discount window borrowing to the interest rate spread between 1998 and 2003 for banks in the USA although an improvement was noted in the subsequent period between 2003 and 2007. The study also attributed the variation in results to increased reluctance to borrow between 1998 and 2003 mainly due to non-price rationing measures and the reform of the discount window borrowing by the Federal Reserve after 2003. The reform involved the introduction of a primary credit facility which greatly reduced the stigma associated with discount window borrowing under the adjustment credit program. The Federal Reserve revised its discount window lending program in 2003 by changing the borrowing terms and using non-price rationing measures to limit access.

Additional methodological improvement was by [17] and [18] who using disaggregated data for banks included a variable to capture the effect of banks expectations about future interest rates. The expectations about future interest rates on their borrowing at the discount window were measured as the expected change in the spread led two weeks forward between the federal funds rate and the discount rate. The findings showed that smaller banks for the most part responded positively to a widening of the Federal funds discount rate spread. However, larger banks were more sensitive to a widening of the spread. On the other hand, the effect of expectations of future interest rate changes produced mixed evidence with negative effects particularly for large banks.

\subsection{Reluctance Theory}

The reluctance theory was developed by [1]. Through the use of indifference curve analysis, he noted that for a given least cost spread between the discount rate and the treasury bill rate, a point existed where the ratio of the marginal utility of profitability and marginal disutility of borrowing was equal to the net rate of profit of the borrowed funds. As the spread increased, the analysis indicated that, new equilibriums would be reached at which the ratio of the marginal utility of profitability and marginal disutility of borrowing would be higher than the previous equilibrium. However, the disutility of such borrowing would be increasing faster than the utility of profitability. This would continue up to a point where the disutility of borrowing relative to the utility of profit would be so large that banks would no longer borrow and could even start repaying their debt obligations to the Central Bank. The conclusion of the study was that this resulted from the reluctance elasticity among banks when borrowing from the Central Bank and that this reluctance increased as the amount of borrowing rose.

Empirical evidence of the theory was provided in [19] through the inclusion of a quadratic term of the spread in the demand equation. The analysis found a significant effect with a negative sign on the square of the spread. [5] tested the reluctance theory in a similar manner but in a model with additional controls for other factors and failed to find evidence in support of the theory. The difference in the results of [5] was attributed to the omission of a control for reserve needs in the model used by [19]. Nonetheless, some limited support was found following the introduction of a cubic term of the spread in the model. [3] following a similar modelling approach to that of [19] and [5] found a statistically insignificant effect of the variable capturing the reluctance effect in a static model. However, the reluctance theory was confirmed in a modified model which took into account partial adjustments in discount window borrowing and reserves.

The greatest support for the reluctance theory is however shown by the studies for the USA considering developments during the 1980's. The different studies established a weak relationship between the spread and discount window borrowing which they attributed to bank reluctance. [18] using a polynomial model highlighted the constraining effect of collateral requirements as one of the factors explaining the reluctance theory. He argued that the requirement for collateral in form treasury securities for discount window borrowing imposed an explicit level of funds a bank could not exceed under normal circumstances. Consequently, banks could not access discount window borrowing once they got to this level irrespective of the attractiveness depicted by the increase in the spread.

[20] related reluctance to administration of discount window borrowing which discouraged banks from exploiting profitable spreads. Similar arguments were made by [21], [10], [22], [12], [8], [11], [15] and [14]. The studies attributed discount window borrowing reluctance to Federal Reserve non-price rationing, operating procedures and accounting rules, improved reserve management efficiency, fear of the public misconstruing discount window borrowing as financial weakness and harassment costs at the discount window.

[21] noted that bank reluctance to discount window borrowing was due to regulatory changes arising from the Federal Reserve, Congressional legislation, and banking-related events on borrowing behavior. Federal Reserve non-price rationing at the discount window and the 
interaction between adjustment credit and extended credit was also provided as the explanation by [10]. [9] provided additional evidence on the reluctance theory which he attributed to changes in the Federal Reserve's operating procedures and reserve accounting rules. The results showed that under the narrow Federal funds rate targeting (1975-79), the spread between the funds rate and the discount rate was relatively predictable and borrowing was sensitive to the spread but became more volatile and unpredictable under the non-borrowed reserves targeting regime (1979-82).

\subsection{Needs Theory}

[5] using a utility function for borrowing cost, identified the need for banks in the United States of America (USA) to meet their reserve requirements as a key motive for liquidating securities also called the needs hypothesis. The needs hypothesis postulates that banks out of different circumstances may face the necessity to increase their reserves. The reserve needs may stem from deposit withdrawals or loan requests. [5] argued that the necessity imposed on the banks could be more important than the market interest and discount interest rates. Consequently banks would increase discount window borrowing to meet their reserve needs. The reserve need theory was tested in the study using current and lagged values of reserves for banks in the USA. The results showed that reserves needs led to increases in discount window borrowing which were statistically significant. [4] also found for banks in Germany that variations in liquidation of securities were positively associated with variations in bank reserves. The results suggested that liquidation of securities tended to redistribute reserves among banks and that this was consistent with the profit theory.

Other studies that empirically investigated the effect of reserves on liquidation of securities include [9] and [3]. [3] did not find for banks in Belgium a significant effect of reserve needs on the liquidation of securities. The model used was similar to that of [5] but the change in reserves variable had a positive sign instead of a negative sign and was not statistically significant at the 5 percent level. [3] attributed the findings to the fact that desired reserves and desired indebtedness responded in an opposite way to the same interest rates. For instance, it was argued that desired reserves would increase as discount rates increased since the adjustment cost for reserve deficiencies increased and reserves would decrease with an increase in the market interest rates as the opportunity cost of holding securities increased. However, this argument can only be valid in an efficient market in which payments systems are working so that there is no need for banks to hold precautionary reserves. This is seldom the case in developing countries.

[9] on the other hand found that increases in required reserves had the expected positive effect on liquidation of securities. However, the effect was not statistically significant at conventional levels. Variants of the model estimated during the Federal funds rate targeting regime (1975 to 1979) and the non-borrowed reserves targeting regimes (1979 to 1982) provided similar findings of an insignificant effect of reserves on liquidation of securities. The estimates only showed support for the reserve needs theory with the correct sign for the sample post 1983 (between 1984 and 1987) which was a period when the Federal Reserve was pursuing a borrowed reserves targeting regime highlighting the role of regulation in explaining the reluctance theory.

\subsection{Accommodation Theory}

The accommodation hypothesis also referred to as the commercial loans theory or real bills doctrine stems from the effect of demand for bank loans on portfolio allocation. According to the theory, borrowing is determined as a residual variable and therefore banks will lend whatever funds they can obtain by selling securities or borrowing from the Central Bank to fully accommodate their customers ([5] and [4]). Thus banks borrow or sell securities in order to meet the temporary loan demand of their customers. [4] in a study on banks in Germany, noted that this theory suggested open market operations of the Central Bank aimed at slowing demand for loans would have little or no effect on bank lending if demand for loans at given interest rates was growing rapidly. The results of the study covering the period from 1974 to 1982 showed that an increase in the demand for loans significantly increased the liquidation of securities. Earlier estimates of [6] covering a shorter period (1980 to 1982) found a much stronger effect of loan accommodation with a short-run elasticity of 1.5 compared to 0.05 in [4]. However, [3] found a statistically significant but negative effect of the test variable for the accommodation hypothesis for banks in Belgium. While [3] did not provide an explanation for the results, it is worth noting that increased loan demand is usually accompanied by increased deterioration in loan quality. The deterioration in loan quality may cause a reversal in loan extension even as loan demand increases. This may cause banks to reduce credit supply in order to limit credit risk and the associated losses which in turn reduce bank liquidation of securities.

The results from the literature reviewed are generally conflicting, sensitive to the period of analysis mainly due to regulatory changes and also vary due to methodological differences. Moreover, all studies reviewed date back several years and do not cover low developing economies from which lessons could be drawn for Uganda. This gap in the literature is addressed by this study using data based on banks in Uganda. This study therefore made three main contributions to the existing literature. Firstly, empirical evidence was provided on the determinants of liquidation of securities in Uganda from which some lessons for developing countries could be drawn. Secondly, a rigorous analytical approach was used comprising of non-linear panel data analysis techniques to ensure adequate modelling of the non-linear nature of the dependent variable (liquidation of securities by commercial banks). Thirdly, since decisions to liquidate are made at the individual bank-level, the study contributed towards a better understanding of the role of individual bank characteristics on liquidation of securities. 


\section{Data Description and Methodology}

\subsection{Data Description}

Analysis used monthly data obtained from Bank of Uganda (BOU) on 12 banks in Uganda that were operational between June 2006 and December 2012. The banks included in the analysis were selected on the basis of having been in operation throughout the period of analysis. This resulted in the exclusion of recently licensed banks and banks which closed or merged with others during the period of analysis. The sample of banks used included both large and small banks, foreign owned and locally owned, old and fairly newer banks and primary dealer and non-primary dealer banks. The sample therefore adequately reflected the character of the entire banking system.

Liquidated securities were measured as the sum of all securities rediscounted during the month and borrowings from the Central Bank for which collateral in form of securities was provided. The spread was computed as the lending rate minus the rediscount rate. The lending rate is a weighted average rate at which banks lend to the non-bank private sector. Movements in both the lending rate and rediscount rate are shown in Figure 1. Lending rates were stable at around 20 percent per annum until July 2011 when they rose, peaking at 27 percent in June 2012. From June 2012, they declined but remained at a higher level of about 25 percent compared to their previous average of 20 percent. The hike in bank lending interest rates after June 2011 closely tracked developments in monetary policy implementation. In July 2011, BOU adopted an inflation targeting regime and subsequently a CBR (rate at which BOU lends to banks funds for a period of seven days). Due to high inflation at the time of adoption, BOU increased the CBR to constrain credit growth and as a result banks increased their lending rates.

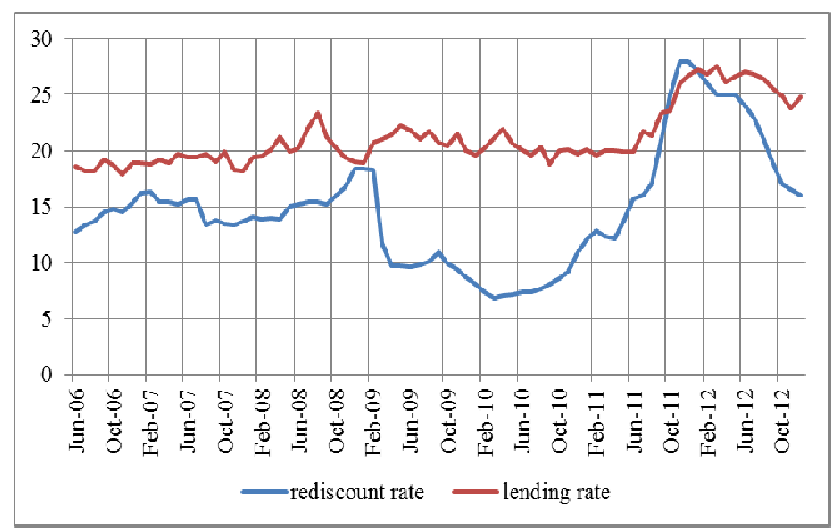

Figure 1. Lending and rediscount rates (percent).

The rediscount rate which is the 91-day treasury bill rate plus a policy margin of the Central Bank for each month also rose dramatically after June 2011 highlighting the monetary policy tone during the period. The rediscount rate rose from about 15 percent in June 2011 to a high of 28 percent in November 2011 before falling sharply to about 16 percent in December 2012 close to its original level prior to the increase.
Although the lending rate rose sharply tracking the increase in the rediscount rate during the period, the deceleration in the rediscount rate was not matched by a reduction in the lending rate. Commensurately, the spread was at its lowest around December 2008 and January 2012 respectively. However, by the end of December 2012, the spread had recouped its earlier decline to about 9 percent.

Reserves of banks were measured as the sum of bank deposits at BOU including both shilling and foreign currency deposits and all shilling and foreign currency denominated notes and coins held by banks. Loans included all shilling and foreign currency loans and advances by banks to their clients. Additional details of the salient features of the data used are shown in Table 1.

Some transformations were also made to some variables prior to their use in the analysis. The transformations included converting all variables with shilling units to logs.

Table 1. Descriptive statistics for determinants of liquidation of bank securities.

\begin{tabular}{lllll}
\hline Variable & Mean & Std. Dev. & Min & Max \\
\hline Figures in percent & & & & \\
Lending rate (1) & 21.18 & 2.6255 & 17.89 & 27.58 \\
Rediscount rate (r) & 14.81 & 5.2935 & 6.83 & 28.00 \\
Spread (k) & 6.38 & 4.0228 & -2.03 & 14.86 \\
Spread squared (k2) & 56.84 & 57.3999 & 0.06 & 220.70 \\
Figures in UGX billions & & & & \\
Bank reserves (R) & 68.05 & 79.1074 & 0.65 & 529.97 \\
Loan assets(L) & 302.66 & 321.2779 & 2.53 & $1,605.96$ \\
\hline
\end{tabular}

\subsection{Methodology}

From the studies on liquidation of securities, a simple model was developed to test the different hypotheses using data for banks in Uganda at the level of individual banks. The approach used for developing the model follows [23] whose estimation strategy combined the various theories. From the model, liquidation of securities depends on the Central Bank's discount rate $(r)$, the rate of interest on alternative sources of reserves or the interbank rate such as borrowing in the inter-bank market $(i)$, the strength of loan demand $(L)$, and variations in total bank reserves $(R)$. Therefore the joint specification for the liquidation of securities can be formalized as:

$$
\begin{array}{r}
\mathrm{BR}=\mathrm{a}_{0}+\mathrm{a}_{1} \mathrm{i}+\mathrm{a}_{2} \mathrm{r}+\mathrm{a}_{3} \mathrm{~L}+\mathrm{a}_{4} \mathrm{R} \\
\mathrm{a}_{1}, \mathrm{a}_{3}, \text { and } \mathrm{a}_{4}>0, \mathrm{a}_{2}<0
\end{array}
$$

Equation (1) can be re-rewritten to test the profit maximization theory by combining the effects of the interbank rate and the rediscount rate to obtain a variable that indicates the relative movements of the two variables as follows:

$$
\begin{gathered}
B R=b_{0}+b_{1}(i-r)+b_{2} L+b_{3} R \\
b_{1}, b_{2} \text {, and } b_{3}>0
\end{gathered}
$$

To be able to test the reluctance theory, Equation (2) is augmented with the square of the spread between the 
interbank rate and rediscount rate with the resultant equation as follows:

$$
\begin{gathered}
\mathrm{BR}=\mathrm{c}_{0}+\mathrm{c}_{1}(\mathrm{i}-\mathrm{r})+\mathrm{c}_{2}(\mathrm{i}-\mathrm{r})^{2}+\mathrm{c}_{3} \mathrm{~L}+\mathrm{c}_{4} \mathrm{R} \\
\mathrm{c}_{1}, \mathrm{c}_{3}, \mathrm{c}_{4}>0 \text { and } \mathrm{c}_{2}<0
\end{gathered}
$$

The study estimated Equation (3) using the logistic model. The logistic model was selected due to the non-linear nature of the dependent variable (amount of liquidated securities) which in some periods was zero. The variable for the amount of liquidated securities was transformed into a binary variable taking on a value of 1 in the period during which a bank liquidated its securities and 0 otherwise. [7], [11] and [18] acknowledged the superiority of non-linear models over linear models when modelling the demand for liquidation of securities.

The model that was fitted follows from the underlying latent model given by:

$$
\begin{aligned}
\mathrm{BR}_{\mathrm{it}}^{*}=\alpha_{\mathrm{i}}+\mathrm{x}_{\mathrm{it}}^{\prime} \beta+\varepsilon_{\mathrm{it}} \\
f\left(\mathrm{BR}_{\mathrm{it}}, \ldots, \mathrm{BR}_{\mathrm{iT}}\right)=\int\left[\Pi _ { \mathrm { t } = 1 } ^ { \mathrm { T } } \Lambda \left(\alpha_{\mathrm{i}}+\mathrm{x}_{\mathrm{i}}^{\prime} \beta\right.\right.
\end{aligned}
$$

for

$$
i=1, \ldots, N ; t=1, \ldots, T
$$

where $B R_{i t}^{*}$ is the continuous but unobserved variable for liquidation of securities by bank $i$ in period $t, x_{i t}^{\prime}$ is a vector of explanatory variables and $\beta$ the respective coefficients, and $\alpha_{i}$ is a fixed or random effect. Rather than observing $B R_{i t}^{*}$, we observe

$$
\mathrm{BR}_{\mathrm{it}}=\left\{\begin{array}{c}
1 \text { if } \mathrm{BR}_{\mathrm{it}}^{*}>0 \\
0 \text { otherwise }
\end{array}\right.
$$

for $\varepsilon_{i t}$ independently logistic,

The logit individual-effects model can be specified as

$$
\operatorname{Pr}\left(\mathrm{BR}_{\mathrm{it}}=1 \mid \mathrm{x}_{\mathrm{it}}, \beta, \alpha_{\mathrm{i}}\right)=\Lambda\left(\alpha_{\mathrm{i}}+\mathrm{x}_{\mathrm{it}}^{\prime} \beta\right)
$$

where $\alpha_{i}$ may be a fixed effect or a random effect.

The logit random effects model specifies that $\alpha_{\mathrm{i}} \sim \mathrm{N}\left(0, \sigma_{\alpha}^{2}\right)$. The joint density for the $i^{\text {th }}$ observation after integrating out $\alpha_{i}$ is

$$
\begin{aligned}
& \left.\beta)^{B R_{i t}}\left\{1-\Lambda\left(\alpha_{i}+x_{i t}^{\prime} \beta\right)^{B R_{i t}}\right\}^{1-B R_{i t}}\right] \\
& g\left(\alpha_{i} \mid \sigma^{2}\right) d \alpha_{i}
\end{aligned}
$$

where $\mathrm{g}\left(\alpha_{\mathrm{i}} \mid \sigma^{2}\right)$ is the $\mathrm{N}\left(0, \sigma_{\alpha}^{2}\right)$ density.

The Hausman test was used to test whether the individual effects were random or fixed.

\section{Results}

\subsection{Logistic Regression Estimates for Bank Liquidation of Securities}

Table 2 provides the logit estimates for four models. The results provide estimates based on the random and fixed effects models. In columns labelled 1 and 2, results are presented for the random and fixed effects models with the covariates comprised of the spread, reserves and loans. In columns labeled 3 and 4, the covariates for the respective random and fixed effects models are the square of the spread, the reserves and loans.

The loan and reserve variables were converted to logs in the model for ease of interpretation. Correlation tests indicated that the spread and square of the spread were highly correlated. The two variables were therefore included in separate models to test for both the profit maximization and reluctance theories. A comparison of the random effects and fixed effects model showed that the random effects models were better. For instance, the Hausman statistics of 1.39 and 1.42 led to rejection of the models with fixed effects. Secondly, the effect of reserves on the likelihood of liquidating securities was only significant in the models with random effects. The discussion of the results is therefore limited to the random effects models in the columns labelled (1) and (3).

Table 2. Logistic regression estimates for bank liquidation of securities.

\begin{tabular}{lllll}
\hline & (1) Random effects model & (2) Fixed effects model & (3) Random effects model & (4) Fixed effects model \\
\hline Constant & -0.49 & - & -0.67 & - \\
& {$[0.4571]$} & & {$[0.4425]$} & \\
Spread & -0.05 & -0.05 & & -0.003 \\
& {$[0.0170]^{* * *}$} & {$[0.0172]^{* * *}$} & -0.003 & {$[0.0012]^{* *}$} \\
Spread squared & & & {$[0.0012]^{* * *}$} & 0.80 \\
& & & 1.19 & {$[0.5751]$} \\
Bank reserves & 1.21 & 0.80 & {$[0.4499]^{* * *}$} & -0.24 \\
& {$[0.4504]^{* * *}$} & {$[0.5731]$} & -0.61 & {$[0.5744]$} \\
Loan assets & -0.64 & -0.31 & {$[0.4563]$} & 948 \\
& {$[0.4575]$} & {$[0.5779]$} & 948 & -600 \\
No. observations & 948 & 948 & -634 & $1.42(3)$ \\
Log-likelihood & -633 & -599 & & \\
Hausman test $(d f)$ & & $1.39(3)$ & & \\
\hline
\end{tabular}

Notes: Coefficients and not odds ratios are presented in the table while figures in parenthesis are ordinary standard errors. * indicates the coefficient is significant at 10 percent; ** is significant at 5 percent; and *** is significant at 1 percent. 
The results in column labelled (1) showed that the spread had a significant negative effect on the likelihood of liquidating securities. A one percent change in the spread resulted in a reduction of 0.05 percent in the likelihood of liquidating securities. This result contradicts the profit maximization theory which hypothesizes that banks liquidate securities as market interest rates for alternative investments rise relative to the rediscount rate. Moreover, the result was the same irrespective of whether the market rate for alternative investments used to derive the spread was the treasury bill rate, interbank lending rate or the lending rate.

The other important finding was on the effect of reserves on bank's liquidation of securities. An increase in the reserves of banks had a significant positive effect on the likelihood of liquidation of securities. The estimates indicated that an increase of one percent in the reserves of banks increased the likelihood of liquidating securities by 1.2 percent. The results did not show any evidence in support of the accommodation theory as increases in loan assets of banks did not have a significant effect on the likelihood of liquidating securities. This result is inconsistent with the theoretical expectations.

The result of a negative effect of the square of the spread on bank liquidation of securities alludes to bank reluctance to liquidate securities. Indeed, estimates in the column labeled (3) indicate a negative significant effect of the square of the spread on the likelihood of liquidating securities. An increase in the square of the spread of 1 percent results in a reduction of the likelihood of liquidating securities of 0.003 percent. The effect is quite small but nonetheless significant which indicates that banks find the marginal disutility of liquidating securities exceeds the marginal utility of profitability at substantially high values of the spread. This result in a way alludes to the possibility of bank reluctance to borrow from the Central Bank as the main reason for the observed significant and negative effect of the spread on liquidation of securities.

\subsection{Logistic Regression Estimates for Liquidation of Securities among Medium and Small Banks}

Additional estimates were obtained based on the random effects model for a sample of banks excluding three of the largest banks (Barclays, Stanbic and Standard Chartered). The results are shown in Table 3.

The findings for the sub-sample of banks excluding the largest three banks were similar to those for the full sample of banks for the effect of the spread, square of the spread and bank reserves on the likelihood of liquidating securities. For instance, a one percent change in the spread resulted in a reduction of 0.05 percent in the likelihood of liquidating securities contradicting the profit maximization theory. An increase in the reserves of banks of one percent increased the likelihood of liquidating securities by 1.2 percent confirming the needs hypothesis. For the square of the spread, an increase of one percent led to a reduction in the likelihood of liquidating securities of 0.003 percent.
Table 3. Logistic regression estimates for liquidation of securities (excludes rediscounts of the largest 3 banks).

\begin{tabular}{lll}
\hline & (1) Random effects model & $\begin{array}{l}\text { (2) Random effects } \\
\text { model }\end{array}$ \\
\hline Constant & -0.01 & -0.22 \\
Spread & {$[0.5257]$} & {$[0.5067]$} \\
& -0.05 & \\
Spread squared & {$[0.0199]^{* *}$} & \\
& & -0.003 \\
Bank reserves & 1.26 & {$[0.0014]^{* *}$} \\
& {$[0.5214]^{* *}$} & 1.21 \\
Loan assets & -0.92 & {$[0.5199]^{* *}$} \\
& {$[0.5103]^{*}$} & -0.85 \\
No. observations & 711 & {$[0.5070]^{*}$} \\
Log-likelihood & -470 & 711 \\
\hline
\end{tabular}

Notes: Coefficients and not odds ratios are presented in the table while figures in parenthesis are ordinary standard errors. * indicates the coefficient is significant at 10 percent; $* *$ is significant at 5 percent; and $* * *$ is significant at 1 percent.

On the other hand, while no conclusive evidence could be obtained from the estimates based on all banks with respect to the accommodation hypothesis, estimates excluding the largest three banks confirmed rejection of the accommodation hypothesis. The results showed that an increase of one percent in the loan assets of banks resulted in a statistically significant reduction in the likelihood of rediscounting securities of 0.9 percent. The result confirms particularly for small banks that bank financing of loans is not sourced through liquidation of securities but rather through other sources.

\section{Discussion of Results}

The results from the analysis failed to find evidence in support of a positive effect of the spread between the rediscount and lending rate on liquidation of securities. On the contrary, a negative significant effect was found implying that banks in Uganda are less inclined to liquidate securities as a means of improving their profitability. Although the result is unexpected, several studies for the USA ([12]; [11]; [14]; [8]; and [16]) also found a break in the relationship between the spread and bank liquidation of securities starting in the late 1980's. The studies attributed the break in the relationship to increased reluctance to liquidate securities partly due to the fear of signaling financial weakness and regulatory changes.

In Uganda's case, one of the regulatory changes that occurred during the period of analysis was the increase in the capital requirements in 2010 from UGX 4 billion to UGX 25 billion to cushion depositors and creditors ([24]). However, the implementation of the increase in capital was phased and it is unlikely that it could have had an effect. It is therefore plausible that banks in Uganda are reluctant to liquidate their securities for fear of signaling weak financial position and management to the Central Bank. Another possible reason 
could be that an increase in the spread results from banks tightening of credit to limit access to funds by subprime borrowers. In many instances, such tightening is usually accompanied by other non-price tightening measures such as more stringent collateral requirements. Where this is the case, an increase in the spread would not necessarily translate into a liquidation of securities to expand credit.

The findings also failed to provide any evidence of the loan demand accommodation hypothesis. Theoretically, an increase in the demand for loans is expected to be accommodated by a reallocation of the available liquid assets such as securities to loans ([5] and [4]). On the contrary, the results showed that increases in loan assets of banks had an opposite effect on liquidation of Government securities. While this finding contradicts the theoretical expectation, it is not unique to only Uganda as [3] also found results that contradicted the accommodation hypothesis for banks in Belgium. The rejection of a significant influence of loan demand could be linked to the fact that loan expansion in Uganda is usually followed with an increase in the non-performing loans. This is because banks generally tend to maximize lending to prime borrowers and to minimize lending to subprime borrowers. As a result most of the loan growth is in the category of subprime borrowers which is usually followed by an increase in non-performing loans. This argument is supported by the finding of a borderline significant effect for loan demand in the subsample excluding large banks where lending to subprime borrowers is likely to be prevalent.

The analysis also provided results in support of the reluctance hypothesis. The effect of the square of the spread on rediscounting of securities is however relatively small compared to the other significant effects with a one percent change in the square of the spread resulting in a 0.003 percent reduction in liquidation of securities. In addition, it is much smaller compared to the result found for banks in Belgium by [3]. [3] found a significant positive effect for banks in Belgium of about a 0.06 percent compared to 0.003 percent found for banks in Uganda. Overall, the results support the notion that as the spread between the rediscount rate and yields on securities increases, banks find that at very high levels of the spread, any gains from rediscounting securities would be outweighed by the costs associated with the reduction in liquidity. The finding demonstrates the importance banks attach towards ensuring that they maintain liquidity even if it means foregoing some profit. This behavior is normal for banks in less developed countries where high levels of liquidity may be maintained for different reasons. [25] highlighted some of the reasons including precautionary purposes where there are poorly developed interbank markets that make it difficult for banks to borrow in order to cover contingencies and to meet demands of remote branches where there are payments system problems. The result could also be due to implicit costs that make it costly to rediscount securities such as the turnaround time to conclude the transaction and administrative requirements. In addition, collateral limitations and regulatory effects could also have a role in explaining this effect.

Further, the findings showed evidence of the needs hypotheses as an increase in reserves increases the likelihood of rediscounting. The effect of reserves is quite large compared to the other significant effects, and is much larger compared to the results for banks in Germany of [26]. [26] found a significant positive effect for banks in Germany of about a half percent compared to 1.2 percent found for banks in Uganda. This result confirms that securities are important for meeting reserve needs. Moreover, compared to the effect of loan demand, it is evident that securities are more important for meeting reserve needs compared to credit demand. A potential implication of this result is that the use of securities by banks to meet reserve needs could be a cheaper option compared to other alternatives such as borrowing or owners increasing their equity. More importantly, it explains why banks have a large share of securities in their portfolio. There are hardly any other securities beside Government debt securities that can be easily liquidated. Overall, the findings indicate lack of sufficient liquidity in the secondary market and alternative liquid securities beside Government debt securities.

\section{Conclusion}

This paper investigated the determinants of liquidation of Government securities held by banks. The findings showed that banks liquidate their securities to primarily meet reserve needs. This result highlights some shortcomings in the secondary market that constrain sales of Government securities. In an ideal situation, the secondary market should be able to provide enough demand for securities to eliminate the need to go to the Central Bank to liquidate the securities. In addition, the findings also highlight some deficiencies in the interbank market. Reserve needs of banks with shortages should be ably accommodated through interbank borrowing from banks with surplus funds at costs that are low compared to liquidating securities.

The results also provided evidence of bank reluctance to liquidate securities as banks are unwilling to take advantage of large increases in the spread. This could be related to the implicit costs associated with liquidation of securities, regulatory effects and collateral limitations. The findings refuted the loan demand accommodation hypothesis as an increase in loan demand did not result in an increase in the likelihood for liquidating securities. This finding confirms the perception that banks in Uganda are risk averse and subsequently unwilling to lend funds for higher profits despite higher lending rates compared to yields on Government securities.

Going forward, there is need to improve the viability of bank's access to interbank credit at competitive rates so that banks do not resort to liquidation of securities to meet reserve needs. In addition, measures to foster increased secondary market activity need to be pursued. Such actions could include diversifying the investor base for government securities, licensing of brokers and increased human intermediation by 
sales people. Diversification of the investor base could be through encouragement of contractual savings groups including pension and provident funds as highlighted by [27]. The Central Bank also needs to address the negative perceptions of liquidating securities and other measures to reduce the costs and risks associated with lending to the private sector.

The empirical results of the study are for the most part consistent with the observations from the data and plausible given what is known about bank's behaviors in the literature and what is known about banks in Uganda. However, the finding on the influence of the spread on liquidation of securities is contrary to the profit theory. The results of this study show that an increase in the spread between the rediscount rate and lending interest rate results in a reduction in the liquidation of securities although an increase in the liquidation of securities would be the expected. While this study makes an attempt to explain possible reasons why the results deviate from theoretical expectations, further investigation on why this seems to be the case is a potential area of research.

\section{References}

[1] M. E. Polakoff, "Reluctance elasticity, least cost, and member bank borrowing: A suggested integration," The Journal of Finance, pp. 1-18, 1960.

[2] L. C. Andersen and A. E. Burger, "Asset management and commercial bank portfolio behavior theory and practice," The Journal of Finance, pp. 207-222, 1969.

[3] H. Langhor, "Banks borrowing from the Central Bank and reserve position doctrine: Belgium 1960 - 1973," Journal of Monetary Economics, pp. 107-124, 1981.

[4] J. Thornton, "Bank rediscounting at the Central Bank," The South African Journal of Economics, 1986.

[5] M. S. Goldfield and J. E. Kane, "The determinants of member-bank borrowing: An econometric study," The Journal of Finance, p. Vol. 21, 1966.

[6] J. Thornton, "The role of rediscount quotas: Note," Journal of Money, Credit and Banking, pp. 387-390, 1985.

[7] D. H. Dutkowsky, "The demand for borrowed reserves: A switching regression model," The Journal of Finance, pp. 407-424, 1984.

[8] J. P. Dow Jr, "The recent behaviour of adjustment credit at the disount window," Journal of Macroeconomics, pp. 199-211, 2001.

[9] D. K. Pearce, "Discount window borrowing and the Federal Reserve operating regimes," Economic Inquiry, pp. 564-579, 1993.

[10] A. M. Meulendyke, "US monetary policy and financial markets," Monograph, 1998.
[11] T. F. Cosimano and R. G. Sheehan, "Is the conventional view of discount window borrowing consistent with the behaviour of weekly reporting banks?," The Review of Economics and Statistics, pp. 761-770, 1994.

[12] K. Mitchell and D. K. Pearce, "Discount window borrowing across Federal reserve districts: Evidence under contemporaneous reserve accounting," Journal of Banking and Finance, pp. 1029-1051, 1992.

[13] S. Peristiani, "The growing reluctance to borrow at the discount window: An empirical investigation," Review of Economics and Statistics, pp. 611-620, 1998.

[14] D. H. Dutkowsky and S. K. McCoskey, "Near integration, bank reluctance and discount window borrowing," Journal of Banking and Finance, pp. 1013-1036, 2001.

[15] M. Goodfriend, "Discount window borrowing, monetary policy, and the post-October 6, 1970 Federal Reserve operating procedure," Journal of Monetary Economics, pp. 343-356, 1983.

[16] E. Artuc and S. Demiralp, "Discount window borrowing after 2003: The explicit reduction in implicit costs," Journal of Banking and Finance, pp. 825-833, 2010.

[17] K. Hamdani and S. Peristiani, "A dissagregate analysis of discount window borrowing," Federal Reserve Bank of New York Quarterly Review, pp. 52-62, 1991.

[18] S. Peristiani, "The model structure of discount window borrowing," Journal of Money, Credit and Banking, pp. 13-34, 1991.

[19] M. E. Polakoff, "Federal Reserve discount policy and its critics," 1963.

[20] P. A. Tinsley, H. T. Farr, B. Garrett and P. Von Zur Muehlen, "Policy robustness: Specification and simulation of a monthly money market model," Journal of Money, Credit and Banking, pp. 829-856, 1982.

[21] C. Kao and D. H. Dutkowsky, "An application of nonlinear bounded influence estimation to aggregate bank borrowing from the Federal Reserve," Journal of the American Statistical Association, pp. 700-709, 1989.

[22] J. A. Clouse, "Recent developments in discount window policy," Federal Reserve Bulletine, 80, p. 965, 1994.

[23] J. Thornton, "The demand for borrowed reserves: Some evidence from West Germany," The American Economist, pp. 41-43, 1987.

[24] Bank of Uganda, "Annual Bank Supervision Report," Kampala, 2010.

[25] M. Saxegaard, "Excess liquidity and effectiveness of monetary policy: Evidence from sub-Saharan Africa," 2006.

[26] D. L. Thornton, "The borrowed-reserves operating procedures theory and evidence," Federal Reserve Bank of St. Louis Review, 1988.

[27] G. Heenan, "A framework for developing secondary markets for government securities," International Monetary Fund, 2004. 